\title{
Evaluation of Different Functional Antioxidant Groups and Protein Responses in Asian Seabass (Lates calcarifer Bloch, 1970) as an Early Indication of Fish Health in Aquaculture Farms.
}

\section{Mohamad Sofi Abu Hassan}

Universiti Malaysia Terengganu

Siti Nur Tahirah Jaafar ( $\square$ tahirah@umt.edu.my )

Universiti Malaysia Terengganu https://orcid.org/0000-0001-5857-8700

Nurulnadia Yusoff

Universiti Malaysia Terengganu

Nik Nurasyikin Nik Azmi

Universiti Malaysia Terengganu

Research article

Keywords: Aquaculture, Asian seabass, Protein damages, Antioxidants, Oxidative stress, Sustainable, Earth

Posted Date: August 31st, 2020

DOI: https://doi.org/10.21203/rs.3.rs-57373/v1

License: (c) (i) This work is licensed under a Creative Commons Attribution 4.0 International License.

Read Full License 


\section{Abstract}

The study was conducted to investigate the organ-specific antioxidants and protein damages responses in Lates calcarifer inhabiting different aquaculture farms that susceptible to different threat of pollutions. Enzymes at the front line of antioxidant system superoxidase dismutase (SOD) and catalase (CAT) evidenced to work together but respond differently in different body compartment. High SOD responses were followed with lower CAT responses observed in muscle $(p<0.05)$ with opposite responses exhibited by both gill and liver. The responses of SOD and CAT in muscle also showed a significant strong correlation to each other (Setiu Wetland: 0.91, Semerak: 0.79) $(p<0.01)$. The glutathione-dependent enzymes, glutathione-s-transferase (GST) and glutathione reductase (GR) in body compartments responded with a strong correlation to each other especially in muscle (Tumpat; muscle: 0.89, gill: 0.95 and liver: 0.54 ( $<<0.01, p<0.05)$, (Setiu Wetland; muscle: $0.72(p<0.01)$ and Semerak; muscle: 0.79 ( $p<$ 0.01). Opposite results were found for both protein damages biomarkers, thiols (-SH-) and carbonyl (-CH-) in comparison to biomarkers responses. In contrary to (-SH-) inconsistent results were observed for the ($\mathrm{CH}-$ ) with muscle found to be most oxidised. The responses of SOD, CAT, GST, GR, thiols and carbonyl were all computed into the same scale through Integrated Biomarker Score (IBR) to classify each aquaculture farms based on biomarkers responses. There was a slight variation in deviation score (A) between organs within the range of (5-7). However, Tumpat overall showed the highest IBR score and significantly higher $(p<0.05)$ than Setiu Wetland with a total score of combining responses score in all three organs (IBR: 84 , muscle: 31, gill: 24, and liver: 29) followed by intermediate score in Semerak (IBR: 72, muscle: 23, gill: 23 and liver: 26) and Setiu Wetland (IBR: 59, muscle: 18, gill: 23 and liver: 18). These results indicated that the responses of antioxidant enzymes and protein damages in L.calcarifer from different organs are heterogeneous. Therefore, biomarkers should be selected based on their sequential groups in the antioxidant system for a better explanation of the oxidative stress evaluation in fish.

\section{Introduction}

Aquaculture sector is essential in Malaysia as an engine of growth for the nation's economy. National Agro-food Policy (2011-2020) in Malaysia estimated that the annual demand of fish will increase from 1.7 million tons in 2011 to 1.93 million tons by the year of 2020 with increasing preference for a healthy source of fish (Yusoff, 2015). The growing population also put aquaculture fish production on a higher demand from 525,000 tons in 2011 to 790,000 tons in 2020 (DOF, 2012). The initiated program by Department of Fisheries (DOF) through Aquaculture Industrial Zone (AIZ) Program involves the development of 49 zones of aquaculture sites across Malaysia for high value aquatic species (Anon, 2009). This effort requires support from many aspects and biomonitoring of fish health is essential to support the program. Marine and brackishwater aquaculture in Malaysia is dominated by three groups of fish, the Asian seabass (Lates calcarifer Bloch, 1970) various snappers Lutjanus spp. and high-value groupers (Othman et al., 2017). Malaysia together with Thailand, Australia, Taiwan and Indonesia are the leading producers of L.calcarifer in the world (Boonyaratpalin \& Williams, 2002). Global capture production for L.calcarifer showed that almost 100 thousand tons of this species were captured in 2010 
and the number kept increasing showing high demand for this species (FAO, 2016). Therefore, there is a need for a sustainable production of this highly commercial fish to meet the population demands.

Various studies have been conducted on the subject of fish diseases for the betterment of Asian seabass production such as vibriosis (Nor et al., 2019) scale drop diseases (SDD) (de Groof et al, 2015; Senapin et al., 2019), fin rot and skin ulcer diseases (Loganthan et al., 1989) and Eimeria infection (Gibson-Kueh, 2012). However, a study on the oxidative stress as biomarkers for the fish that acts as precursors to other diseases has rarely been the subject of interest among researchers in L.calcarifer. Antioxidant biomarkers have been widely explored in human study to detect various arrays of diseases such as diabetes, Alzheimer's, cancer, tumour and corneal diseases (Giacco \& Brownlee, 2010; Galasko et al., 2012; Vallabh et al., 2017). Fish possess the same defending system as human in preventing the attack of reactive and dangerous radicals in the body system triggered by pollutants in their ecosystem (Poljšak \& Fink, 2014). The same application could be used in the aquaculture system to access the health of the fish before it becomes untreatable. However, a good understanding in the response of the antioxidant system in their body is important for further development of a good biomarker. Therefore, there is a need to identify the responses of antioxidant enzymes and protein damages in L.calcarifer that can provide early oxidative stress indication in fish and prevent the disease outbreaks in aquaculture farms.

This study emphasized on the responses of antioxidant system in the extent of their smaller functional classification in their defending system toward active radicals. The organs-specific antioxidant biomarker responses was quantified and observed in the first-line defense of antioxidant system and the glutathione dependent enzymes system. Further the oxidative damages that occurred in the fish were measured through protein damages biomarker. This hopes for a better understanding on these biomarkers responses in L.calcarifer for future potential use as early measurable indicators of fish health in aquaculture farm industry for a sustainable production of this species.

\section{Methods/experimental}

\section{Sample collection}

Market ready sizes of $( \pm 500 \mathrm{~g})$ L.calcarifer samples were obtained from three main aquaculture farms on the east side coast of peninsular Malaysia as shown in Fig. 1. Twenty biological replicates $(n=20)$ of $L$. calcariferwere selected from each aquaculture farm in Setiu Wetland, Semerak and Tumpat. The fish were directly selected from the cage farms and only physically healthy condition fish was selected to be used for experiment analysis. Prior to dissection, the sampled fish were anaesthetized after the selection from the cage to avoid stress during handling. After weighing and measuring, each sampled fish was immediately dissected for muscle gill and liver. All organs were weighed for extraction estimation ratio with extracting buffer and immediately stored at $-80^{\circ} \mathrm{C}$ to avoid protein degradation. All animals used were strictly in accordance to EU Directive 2010/63/EU for animal experiments. 


\section{Antioxidant Activity}

One individual sampled L.calcarifer represents one biological replicate for every targeted antioxidant activity, superoxidase dismutase (SOD), catalase (CAT), glutathione-s-transferase (GST) and glutathione reductase (GR). Twenty biological replicates with three technical replicates (triplicates) for each organ were used for antioxidant analysis to avoid bias and errors in accordance to Animal Research: Reporting of In Vivo Experiments (ARRIVE) guidelines.

All samples were extracted using homogenizer (ULTRA TURREX) in $10 \mathrm{mM}$ Tris - HCL buffer (pH 7.2) and the post-mitochondrial supernatants (PMS) was obtained after centrifugation at $15000 \mathrm{Xg}$ and $4^{\circ} \mathrm{C}$ for one hour (Jaafar et al, 2015). Protein mass determination was done for all samples following Bradford assay using Bovine Serum Albumin (BSA) as a standard (Bradford, 1976).

All analysis was done using spectrophotometric method with different wavelength used for each antioxidant enzyme depending on the nature of each bioassay. SOD assay with xanthine oxidase as based was used in quantifying the SOD activity following the method by (McCord \& Fridovich, 1969) with modifications. $62.5 \mathrm{mM}$ of potassium phosphate $(\mathrm{pH} 7.8)$ was prepared together with $0.125 \mathrm{mM}$ EDTA, $83.3 \mu \mathrm{M}$ hypoxanthine and $16.7 \mu \mathrm{M}$ Cytochrome $\mathrm{C}$ added freshly to the buffer on the day of the assay being performed. Xanthine oxidase was added to each prepared well and absorbent readings were measured kinetically at $550 \mathrm{~nm}$ by using multi- mode Microplate reader (Molecular Devices model SpectraMax iD3) for every 30 seconds for 5 minutes. The absorbency readings were then used to calculate the activity of SOD by taking the reading of $50 \%$ inhibition from each sample read. CAT activity was assayed following (Aebi, 1974) by observing the decrease of absorbance due to the consumption of hydrogen peroxide $\left(\mathrm{H}_{2} \mathrm{O}_{2}\right)$ at $240 \mathrm{~nm}$ (extinction coefficient: $\mathbb{\nabla}=0.04 \mathrm{mM}^{-1} \mathrm{~cm}^{-1}$ ) using spectrophotometer. The decrease of absorbance was followed kinetically for 5 minutes with 30 seconds' interval.

The activity of GST was measured following the method of Habig et al. (1974) in 0.15M potassium phosphate buffer $(\mathrm{pH} 6.5)$ and 1- chloro-2,4-dinitrobenzene as substrate (extinction coefficient: $\mathbb{\nabla}=$ $\left.9.6 \mathrm{mM}^{-1} \mathrm{~cm}^{-1}\right)$. The increase of absorbance was followed at $340 \mathrm{~nm}$ using multi-mode Microplate reader (Molecular Devices model SpectraMax iD3) for every 30 seconds for 5 minutes. The increase in absorbance was observed due to the conjugation of 2,4-Dinitrochlorobenzene (CDNB) with reduced glutathione (GSH). The GR activity was measured in $0.48 \mathrm{M}$ potassium phosphate buffer $(\mathrm{pH} 7.2)$ and $\beta$ nicotinamide-adenine dinucleotide phosphate reduced form tetrasodium salt ( $\beta$-NADPH) as substrate (extinction coefficient: $\nabla=6.2 \mathrm{mM}^{-1} \mathrm{~cm}^{-1}$; (Carlberg \& Mannervick, 1985). The absorbance was followed at $340 \mathrm{~nm}$ using multi- mode Microplate reader (Molecular Devices model SpectraMax iD3) for 5 minutes with 30 seconds' interval. The decrease of absorbance was observed due to the consumption of $\beta$ $\mathrm{NADPH}$ to convert oxidized glutathione (GSSG) to glutathione (GSH).

\section{Protein Damages}


The replicates concept for the analysis of protein damages, thiols (-SH-) and carbonyls $(-\mathrm{CH}-)$ followed the concept of antioxidant activity with the same sample from biological replicates used for antioxidant activity and followed with 2 gels replicates as technical replicates for each sample. All samples were extracted using homogeniser (ULTRA TURREX) in $10 \mathrm{mM}$ Tris - HCL buffer (pH 7.2) and the postmithochondrial supernatants (PMS) was obtained after centrifugation at $15000 \mathrm{X} \mathrm{g}$ and $4^{\circ} \mathrm{C}$ for one hour (Jaafar et al., 2015). Protein mass determination was done for all samples following Bradford assay using Bovine Serum Albumin (BSA) as a standard (Bradford, 1976).

The thiols-containing protein and carbonyl-containing protein were quantified following the method of (Jaafar et al., 2015) through western blotting technique. Both thiols and carbonyl followed a similar method with a difference in the fluorescent tagged used. The thiols containing protein was labelled using fluorescent tagging 5-iodoacetamido-fluorescein (IAF) and carbonyl-containing protein was labelled using fluorescein-5-thiosemicarbazide (FTSC) in dimethyl sulfoxide (DMSO) to a final concentration of $0.2 \mathrm{mM}$.

The samples were incubated in the dark for two hours after being tagged. 20\% Trichloroacetic acid (TCA) was used to aid precipitation of protein and the tagged samples were centrifuged at $11000 \mathrm{Xg}$ for 3 minutes to obtain the protein precipitates. The protein precipitates were then thoroughly crushed with the aid of sonicator in ice. The crushed protein precipitates were added with $500 \mathrm{ul}$ of cold acetone and incubated overnight to wash away the content of the TCA. The protein precipitates were further centrifuged at $11000 \mathrm{Xg}$ for 3 minutes and the excess acetone was discarded and $10 \mathrm{ul}$ of sample buffer with $\beta$-mercaptoethanol was added for every $20 \mathrm{ug}$ of protein. The tagged protein samples were then boiled at $98^{\circ} \mathrm{C}$ for 3 minutes to separate the protein molecules into a single strand protein. 12 percent resolution gel and 6 percent stacking gel were used to resolve the protein using BioRad Electrophoresis system at a constant voltage $(150 \mathrm{~V})$. Two gels were assigned for each sample as replicates and the gel was scanned after completed. The gels were subsequently stained with colloidal coomasie staining with CBB G- 250 overnight and preceded with gel view again after destaining. The viewed gels for both fluorescent and 1DE gels stained with Coomasie blue G-250 were analyzed using Quantity one image analysis software (Bio-Rad, Hercules, CA, USA) measuring the total intensity of each lane and quantified as an arbitrary unit. Total optical densities for each lane were normalized with Coomasie staining for the same gel.

\section{Integrated Biomarker Responses (ibr) Score}

The deviation score (A) were all plotted as shown in (Fig. 6A, Fig. 6B and Fig. 6C) for every measured biomarker for each study site. The plot graph of the response of multi biomarkers in muscle, gill and liver for all sites only showed a slight variation between biomarkers and the sites with deviation score $(A)$ in the range of (5-7). Tumpat overall showed the highest IBR score (muscle: 31, gill: 24, and liver: 29) for each studied organs and Setiu Wetland showed the lowest score overall (muscle: 18, gill: 23 and liver: 18). Semerak overall showed intermediate scores (muscle: 23 , gill: 23 and liver: 26 ) as shown in Table 3. 
However, overall comparison of IBR score combining all three organs showed that Tumpat was significantly higher $(p<0.05)$ compared to Setiu.

Table 3

The Integrated Biomarker Score for each organ from study sites

\begin{tabular}{|c|c|c|}
\hline & Study site & IBR score \\
\hline \multirow[t]{3}{*}{ Muscle } & Setiu Wetland & 18 \\
\hline & Semerak & 23 \\
\hline & Tumpat & 31 \\
\hline \multirow[t]{3}{*}{ Gill } & Setiu Wetland & 25 \\
\hline & Semerak & 23 \\
\hline & Tumpat & 24 \\
\hline \multirow[t]{3}{*}{ Liver } & Setiu Wetland & 18 \\
\hline & Semerak & 26 \\
\hline & Tumpat & 29 \\
\hline
\end{tabular}

Tumpat was induced with the most pollution that reflected the condition of this place to be the most polluted as compared to the other two sites based on the IBR score. Looking back at the chronology of pollution history occurred in the study sites, Tumpat was implicated with a few environmental events such as Harmful Algal Bloom (HAB) and shellfish intoxication as reported by (Lim et al., 2010: Lim et al., 2012). However, the effects of HABs are temporary and will eventually wear off. Considering the samples were retrieved in 2016, the effect that happened years before might had been worn off since it was not observed or reported happened in the same years of the sampling time. Nevertheless, observations were made during sampling time and it was found that the water system in Tumpat was blocked by a sand mound caused by erosion. This could hamper a good water circulation and trapped more pollutants induced from land considering they are the key to good water quality (Grifoll et al., 2011). Therefore, this could sensibly explain the highest response of both antioxidant and protein damages on this site.

The level of any type of pollutants was not measured or recorded from the present study. Thus, a benchmark on the concentration of a certain pollutant could not be imposed to generalize the result obtained. HABs have not been reported in both Setiu Wetland and Semerak. However, in order to trace the pollution state in Setiu Wetland and Semerak for a possible explanation on the response of biomarker batteries used, literatures on previous studies conducted on these sites were referred. Heavy metals studies conducted in Setiu Wetland on various marine organisms showed a fair condition (Suratman et al., 2014; Shaari et al., 2016; Le et al., 2017). On the other hand, referring to a study conducted in Semerak (Yap \& Chew, 2011; Shaari et al., 2015) on heavy metals content in bivalves showed that the metal 
content in the species studied was mostly below the permissible limit. Therefore, this gave a little insight into the status of these two sites from heavy metals level perspective and in line with the response of biomarkers shown by Setiu Wetland and Semerak.

\section{Results And Discussion}

\section{First-line defense of antioxidant system}

SOD and CAT activity were compared according to the response level in the organs as shown in Fig. 2 . SOD activity in muscle and gill were observed to be significantly lower $(p<0.05)$ compared to the liver in Setiu Wetland. The same pattern was noticed for the response of SOD activity in Semerak with muscle and gill were significantly lower $(p<0.05)$ compared to the liver. CAT showed the same pattern of response with liver remained as the organ with the highest response. Significant results were observed for the response of CAT between organs for all sites $(p<0.05)$. As shown in Fig. 2 the response of CAT in liver was significantly higher compared to both muscle and gill in Setiu Wetland. Meanwhile, in Semerak and Tumpat liver showed a significant higher response compared to both gill and muscle with significant higher response of gill $(p<0.05)$ compared to muscle.

Further, the response level of SOD and CAT were compared as shown in Fig. 3. From the results, it showed that despite the superior SOD response compared to CAT for gill and liver in all studied sites. Muscle appeared to be in the opposite, with significant higher of CAT response $(p<0.05)$ for both Setiu and Semerak followed by a significant strong correlation (Setiu Wetland: 0.91 , Semerak: 0.79$)(p<0.01)$ as shown in Table 1. 
Table 1

Pearson correlation of GST and GR in muscle, gill and liver of L.calcarifer

\section{Setiu Wetland}

\begin{tabular}{|ll|}
\hline Muscle & $\mathbf{0 . 9 1 * *}$ \\
\hline Gill & -0.08 \\
\hline Liver & 0.07 \\
\hline Semerak & \\
\hline Gill & 0.02 \\
\hline Liver & 0.26 \\
\hline Tumpat & 0.65 \\
\hline Muscle & \\
\hline Gill & $0.78 * *$ \\
\hline Liver & 0.37 \\
\hline ** indicates significant correlation $(p<0.01)$ * indicates correlation $(p<0.05)$ \\
\hline
\end{tabular}

This study emphasized on the response of oxidative stress of different tissues in L.calcariferinhabiting different aquaculture farms. The pattern of SOD and CAT in L.calcarifer showed a consistent and convincing outcome that these two biomarkers will respond the most in the liver, followed by gill and muscle. This agrees with studies reported by (Ameur et al., 2012; Beg et al., 2014; Ballesteros et al., 2017) in Mugil cephalus, Dicentrachus labrax, Acanthopagrus latus, Cynoglossus arel and Jenynsia multidentata. From these results it further explains, regardless differences a certain habitat have the response of SOD and CAT in L.calcarifer will respond following the capability of the organ to take up the pollutants as well as the route of xenobitics to get into the body system (Ahmad et al, 2000).

Muscle is often neglected because it is expected to show the least response and it is rarely seen to be used as a target organ by researchers. The present study showed the least SOD and CAT response in muscle as expected which agrees to previous reported studies (dos Santos Carvalho et al., 2012; Maulvault et al., 2018) performed on the muscle of Oreochromis niloticus and Dicenthrachus labrax (European seabass). However, it is important to take into account the importance of this organ since it reflects the route of pollutants into the fish by providing the level of response for each body compartment for a better understanding of how these enzymes respond in a certain organ (Oliveira et al., 2008). Pointing out from this, the response of SOD and CAT in muscle was evidenced to be different from sensitive organs, gill and liver. 
The response in gill and liver agreed to a study reported by (Abhijith et al., 2016) in gill and liver of carp, Catla catla. From this, it explains that both enzymes at the front line of antioxidant system work together but respond differently in different body compartment as evidenced by the present study. This is further supported by the strong correlation shown in muscle. Therefore, it is very important to have these enzymes together as targeted biomarkers because their responses are correlated to each other.

\section{Glutathione-dependent Enzymes System}

The response level of both GST and GR in muscle, gill and liver was compared for each study site as shown in Fig. 4. Overall, the most response was shown in the liver for both enzymes followed by muscle being the least responded organ for all sites. A significant higher response of GST $(p<0.05)$ was observed in the liver for both sites Setiu Wetland and Semerak compared to the muscle. The response of GST in gill for Semerak also observed to be significantly lower $(p<0.05)$ compared to liver. Regarding GR, the responses in liver for all sites were significantly higher $(p<0.05)$ compared to both muscle and gill. The response of both GST and GR were tested using Pearson correlation analysis as shown in Table 2 . There was a strong significant correlation observed for the response of GST and GR in all targeted tissues from Tumpat, muscle: 0.89 , gill: 0.95 and liver: $0.54(p<0.01, p<0.05)$. Strong significant correlations also observed in both sites Setiu Wetland $(0.72)$ and Semerak $(0.79)$ for muscle $(p<0.01)$.

Table 2

Pearson correlation of GST and GR in muscle, gill and liver of L.calcarifer

\begin{tabular}{|ll|}
\hline Setiu Wetland & \\
\hline Muscle & $\mathbf{0 . 7 2 * *}$ \\
\hline Gill & 0.24 \\
\hline Siver & -0.08 \\
\hline Muscle & \\
\hline Gill & $\mathbf{0 . 7 9 * *}$ \\
\hline Liver & 0.25 \\
\hline Tumpat & 0.38 \\
\hline Muscle & \\
\hline Gill & $\mathbf{0 . 8 9 * *}$ \\
\hline Liver & $\mathbf{0 . 9 5 * *}$ \\
\hline ** indicates significant correlation $(p<0.01)$ * indicates correlation $(p<0.05)$ \\
\hline
\end{tabular}


It has been proven in human, rats and reptiles that GST could indicate the organ damages through their defensive responses since GST is considered as non-specific oxidant enzymes that help to detoxify various oxidants (Hermes-Lima \& Storey, 1993; Kilty et al., 1998; El-Demerdash et al., 2009). The results showed liver experienced the most damages compared to gill and muscle. This is also proved by previous studies performed on fish as done by (Simonato et al., 2016; Samantha et al., 2018) since liver acts as a depository organ for various pollutants. The level of GST response was higher compared to GR. This agrees with the previous reported studies (Song et al., 2012; Jaafar et al., 2015; Gianng et al., 2018).

GST activity was expressed in umol/min/mg protein whilst GR activity was expressed in $\mathrm{nmol} / \mathrm{min} / \mathrm{mg}$ protein. This showed that the difference of their responses was apparent. GST is amendable towards various numbers of electrophilic compounds (Habig, 1983; Armstrong, 1997; Strange et al., 2001). This allows it to catalyse non-specific oxidants and result in a higher activity response. The presence of pollutants leads to reduction in the level of GSH and GSH-GSSG ratio and causing reduction in GR activity (Monteiro et al., 2010). Besides, GR is responsible to cater GSH to ensure a proper function of other GSH utilizing enzymes which include GST, Glutathione peroxidase (GPX), Glutaredoxins, glyoxalases 1 and 2 (Hayes et al., 2005; Deponte, 2013; Csiszár et al., 2016). Therefore, the higher responses showed by GST followed their specific functionality in antioxidant system.

Following the specific functionality of both GST and GR, their responses will correlate to each other. This is proven by the strong correlation index obtained. Many studies focussed on different pollutants exposure onto testing organisms with different exposure time that exhibited various induction and reduction of GST and GR responses in different body compartment as reported by (Oliva et al., 2012; Song et al., 2012). However, study on how these two enzymes responses correlated to each other is scarce. Gondhowiardjo (1993) reported a correlation of GST and GR activity in a normal and separate group of corneal disorders in mammal. A similar response could be expected in fish but further studies should be implemented.

\section{Thiols Protein And Carbonyl Protein (protein Damages)}

In general, a consistent pattern was observed for the total thiols containing protein for all three sites (Fig. 5). The response of oxidized thiols in the tissues of L.calcariferwas consistent with muscle remained as the least oxidized tissue followed by gill and liver for all sites. A higher significant result $(\mathrm{p}<$ 0.05) was observed in the liver as compared to gill and muscle in Setiu Wetland. However, no significant results were observed for Semerak and Tumpat.

In contrary to thiols, carbonyl containing protein showed inconsistent results in the targeted tissues as shown in Fig. 5. Insignificant consistent result was observed in Setiu Wetland with liver remained as the most oxidized organ followed by gill and muscle. The same pattern of results was observed for Semerak and Tumpat with muscle as the most oxidized followed by liver and gill. Muscle was significantly $(\mathrm{p}<$ $0.05)$ more oxidized than gill in Semerak and gill was significantly $(p<0.05)$ less oxidized than muscle and liver in Tumpat. 
The response of thiols showed that sensitive organs are more susceptible to damages as evidenced by the consistent oxidized thiols in liver for all study sites. The trend of responses for thiols is different from other targeted biomarkers in the present study considering its mechanism of action. Thiols molecules are present on the side chain of protein and they are very sensitive to the presence of ROS that tend to oxidize them (Dalle-Donne et al., 2005; Rossi et al., 2006). Therefore, the decrease in their numbers indicates damages that happened to the targeted species (Rainville, 2015). The response level of thiols in Mytilus edulis reported by (Todesco et al., 2012) is more pronounced compared to this study and it was evident as a suitable biomarker for biomonitoring. However, the present study only managed to evaluate the pattern and level of oxidative damages that occurred in different body compartments. Nevertheless, the consistent responses in muscle, gill and liver from all aquaculture farms suggest that the antioxidant defenses are correspondingly efficient in each organ of $L$. calcarifer to prevent from reactive oxygen species (ROS) attack. The other reason that supported the responses consistency also related to the possible pathway of pollutants to get into the body compartment of the fish. The response of thiols is comparable with the study done by (Parvez, \& Raisuddin, 2006; Jaafar et al., 2015; Menezeset al., 2016) on different marine species. However, there was no publication reported on the responses of thiols in L.calcarifer. Thus, this could be a baseline data for the response of thiols in this commercially important species.

The more apparent damages indicated by high carbonyl level occurred in muscles for Semerak and Tumpat. The increase of protein damages followed by the decrease of antioxidant enzymes activity showed inefficiency of antioxidant defense (Almroth et al., 2019). Therefore, the results suggesting that the antioxidant defense in muscle is less efficient compared to gill and liver. However, enzymatic antioxidant responses were recorded in the present study and all of them were consistent respectively. Tabassum et al. (2016) has reported an increase in the response of carbonyl content with decreasing response of non-enzymatic antioxidant in Channa punctata Bloch. Therefore, inefficiency might happen in the response of non-enzymatic antioxidant such as (glutathione, ascorbic acid and uric acid) and affected the response of carbonyl. The robustness of antioxidants defense system limited the extent of carbonyl and Lipid peroxidification (LPO) (Barros et al., 2017). Thus, this explains the high response of carbonyl content in muscle for both Semerak and Tumpat were due to the low response of non-enzymatic antioxidant in the present study.

\section{Conclusions}

In conclusion, the present study managed to access the trend of biomarkers' responses in different body compartment of fish following different functionality of each enzymes and protein groups. Besides, this study also managed to classify the pollution state towards multi-biomarker responses of three main fish cage of the east side of Peninsula Malaysia. This information is beneficial to the fish farms industry for early monitoring of diseases and sustainable production of aquaculture produce. However, no specific pollutant could be pointed out that induced responses of biomarkers. Therefore, a further study should be conducted to observe the real condition of the sites and to point out the point source pollutions to decide what pollutants might present the most in the ecosystem. Thus, this will complement the data of the 
biomarkers and they can further be confirmed in the laboratory to see how that certain pollution or to the extent of what concentration of that certain pollutant induces stress to a certain organism in a controlled environment.

\section{Abbreviations}

\section{A}

Deviation Index; AIZ:Aquaculture Industrial Zone; -CH-:Carbonyls; CAT:Catalase; DOF:Department of Fisheries; GST:Glutathione-s-transferase; GR:Glutathione reductase; GSH:Reduced glutathione; GSSH:Oxidised glutathione; HAB:Harmful algal bloom; IBR:Integrated Biomarker Responses; LPO:Lipid peroxidation; ROS:Reactive oxygen species; s:Standard deviation; SOD:Superoxidase dismutase; TH-:Thiols; $u$ :General mean

\section{Declarations}

\section{Availability of data and material}

The datasets used and analyzed during the current study are available from the corresponding author on reasonable request.

\section{Competing interests}

All authors have no financial or other conflicts of interest.

\section{Funding}

This study was funded by the Research Acculturation Grant Scheme (RAGS) grant and Higher Instituition Centre of Excellence (HICoE) grant.

\section{Authors' contributions}

N.N.Y and S.N.T.J proposed the topic, conceived and designed the study. M.S.A.H carried out the experimental study, sample collection, sample analysis, data analysis and responsible in the construction of manuscript. N.N.N.A helped to analyses the data and sample collection. All authors read and approved the final manuscript.

\section{Authors' information}

Correspondence and requests for material should be addressed to SNTJ (tahirah@umt.edu.my)

\section{References}


1. Abhijith BD, Ramesh M, Poopal RK (2016) Responses of metabolic and antioxidant enzymatic activities in gill, liver and plasma of Catla catla during mrthyl parathion exposure. The Journal of Basic Applied of Zoology 77:31-40. https://doi.org/10.1016/j.jobaz.2015.11.002

2. 10.1016/B978-0-12-091302-2.50032-3

Aebi H (1974) Catalase. In Methods of enzymatic analysis (pp. 673-684) Academic press. https://doi.org/10.1016/B978-0-12-091302-2.50032-3

3. Ahmad I, Hamid T, Fatima M, Chand HS, Jain SK, Athar M, Raisuddin S (2000) Induction of hepatic antioxidants in freshwater catfish (Channa punctatus Bloch) is a biomarker of paper mill effluent exposure. Biochimica et Biophysica Acta (BBA)-General Subjects 1523(1):37-48

4. https://doi.org/10.1016/S0304-4165(00)00098-2

5. Almroth BC, de Souza KB, Jönsson E, Sturve J (2019) Oxidative stress and biomarker responses in the Atlantic halibut after long term exposure to elevated $\mathrm{CO} 2$ and a range of temperatures. Comp Biochem Physiol B: Biochem Mol Biol 238:110321. https://doi.org/10.1016/j.cbpb.2019.110321

6. Ameur WB, de Lapuente J, El Megdiche Y, Barhoumi B, Trabelsi S, Camps L, Borràs M (2012) Oxidative stress, genotoxicity and histopathology biomarker responses in mullet (Mugil cephalus) and sea bass (Dicentrarchus labrax) liver from Bizerte Lagoon (Tunisia). Mar Pollut Bull 64(2):241251

7. https://doi.org/10.1016/j.marpolbul.2011.11.026

8. Anon (2009) Department of Fisheries Malaysia. Business Prospectus; Development of high impact projects (HIPO in the aquaculture zone (AIZ). Department of Fisheries, Ministry of Agricultural and Agro-Based Industry. $139 \mathrm{pp}$

9. Armstrong RN (1997) Structure, catalytic mechanism, and evolution of the glutathione transferases. Chem Res Toxicol 10(1):2-18

10. https://doi.org/10.1021/tx960072x

11. Ballesteros ML, Rivetti NG, Morillo DO, Bertrand L, Ame MV, Bistoni MA (2017) Multi-biomarker responses in fish (Jenynsia multidentata) to assess the impact of pollution in rivers with mixtures of environmental contaminants. Sciences of the Total Environment 595:711-722. https://doi.org/10.1016/j.scitotenv.2017.03.203

12. Barros IT, Ceccon JP, Glinski A, Liebel S, Grötzner SR, Randi MAF, de Oliveira Ribeiro CA (2017) Environmental risk assessment in five rivers of Parana River basin, Southern Brazil, through biomarkers in Astyanax spp. Environ Sci Pollut Res 24(19):16228-16240. https://doi.org/10.1007/s11356-017-9186-z

13. Beg MU, Al-Jandal N, Al-Subiai S, Karam Q, Husain S, Butt SA, Al-Husaini M (2015) Metallothionein, oxidative stress and trace metals in gills and liver of demersal and pelagic fish species from Kuwaits' marine area. Mar Pollut Bull 100(2):662-672. https://doi.org/10.1016/j.marpolbul.2015.07.058

14. Beliaeff $B$, Burgeot $T$ (2002) Integrated biomarker response: a useful tool for ecological risk assessment. Environmental Toxicology Chemistry: An International Journal 21(6):1316-1322. https://doi.org/10.1002/etc.5620210629 
15. Boonyaratpalin M, Williams K (2002) Asian sea bass, Lates calcarifer. Nutrient requirements and feeding of finfish for aquaculture, 40-50. https://doi.org/10.1079/9780851995199.0040

16. Bradford MM (1976) A rapid and sensitive method for the quantisation of microgram quantities of protein utilizing the principle of protein-dye binding. Anal Biochem 72(1-2):248-254. https://doi.org/10.1016/0003-2697(76)90527-3

17. $10.1016 / \mathrm{S} 0076-6879(85) 13062-4$

Carlberg I, Mannervik B (1985) Glutathione reductase. In Methods in enzymology (Vol. 113, pp. 484490). Academic press. https://doi.org/10.1016/S0076-6879(85)13062-4

18. Csiszár J, Horváth E, Bela K, Gallé Á (2016) Glutathione-related enzyme system: glutathione reductase (GR), glutathione transferases (GSTs) and glutathione peroxidases (GPXs). In: Redox State as a Central Regulator of Plant-Cell Stress Responses. Springer, Cham, pp 137-158

19. https://doi.org/10.1007/978-3-319-44081-1_7

20. Dalle-Donne I, Scaloni A, Giustarini D, Cavarra E, Tell G, Lungarella G, Milzani A (2005) Proteins as biomarkers of oxidative/nitrosative stress in diseases: the contribution of redox proteomics. Mass spectrometry reviews 24(1):55-99. https://doi.org/10.1002/mas.20006

21. de Groof A, Guelebn L, Deijs M, van der Wal Y, Miyata M, Ng KS, van Lent J (2015) A novel virus causes scale drop disease in Lates calcarifer. PLoS pathogens 11(8)https://doi.org/10.1371/journal.ppat.1005074

22. Deponte $M$ (2013) Glutathione catalysis and the reaction mechanisms of glutathione-dependent enzymes. Biochimica et Biophysica Acta (BBA)-General Subjects 1830(5):3217-3266. https://doi.org/10.1016/j.bbagen.2012.09.018

23. Devin S, Buffet PE, Châtel A, Perrein-Ettajani H, Valsami-Jones E, Mouneyrac C (2017) The integrated biomarker response: a suitable tool to evaluate toxicity of metal-based nanoparticles. Nanotoxicology 11(1):1-6. https://doi.org/10.1080/17435390.2016.1269374

24. DOF (2012) Annual Fisheries Statistics. Department of Fisheries Malaysia org

25. dos Santos Carvalho C, Bernusso VA, de Araújo HSS, Espíndola ELG, Fernandes MN (2012) Biomarker responses as indication of contaminant effects in Oreochromis niloticus. Chemosphere 89(1):60-69. https://doi.org/10.1016/j.chemosphere.2012.04.013

26. El-Demerdash FM, Yousef MI, Radwan FM (2009) Ameliorating effect of curcumin on sodium arsenite-induced oxidative damage and lipid peroxidation in different rat organs. Food Chem Toxicol 47(1):249-254

27. https://doi.org/10.1016/j.fct.2008.11.013

28. FAO (2016) State of World Fisheries and Aquaculture 2016 (french). Food \& Agriculture Org

29. Galasko DR, Peskind E, Clark CM, Quinn JF, Ringman JM, Jicha GA, Aisen P (2012) Antioxidants for Alzheimer disease: a randomized clinical trial with cerebrospinal fluid biomarker measures. Arch Neurol 69(7):836-841. https://doi.org/10.1001/archneurol.2012.85 
30. Giacco F, Brownlee M (2010) Oxidative stress and diabetic compilations. Circulation research 107(9):1058-1070. https://doi.org/10.1161/CIRCRESAHA.110.223545

31. Giang PT, Sakalli S, Fedorova G, Tilami SK, Bakal T, Najmanova L, Grabic R (2018) Biomarker response, health indicators, and intestinal microbiome composition in wild brown trout (Salmo trutta $m$. fario $L$.) exposed to a sewage treatment plant effluent-dominated stream. Science of The Total Environment 625:1494-1509

32. https://doi.org/10.1016/j.scitotenv.2018.01.020

33. Gibson-Kueh S (2012) Diseases of Asian seabass (or barramundi), Lates calcarifer Bloch. Dissertation, Murdoch University

34. Gondhowiardjo TD (1993) Corneal aldehyde dehydrogenase, glutathione reductase, and glutathiones-transferase in pathologic corneas. Cornea 12(4):310-314. https://doi.org/10.1097/00003226199307000-00006

35. Grifoll M, Jordà G, Espino M, Romo J, García-Sotillo M (2011) A management system for accidental water pollution risk in a harbour: the Barcelona case study. J Mar Syst 88(1):60-73. https://doi.org/10.1016/j.jmarsys.2011.02.014

36. Habig WH (1983) Glutathione-s-transferase: versatile enzymes of detoxication. In: Radioprotectors and anticarcinogens. Academic Press, New York, pp 169-190

37. Habig WH, Pabst MJ, Jakoby WB (1974) Glutathione-s-transferases the first enzymatic step in mercapturic acid formation. Journal of biological Chemistry 249(22):7130-7139

38. Hayes JD, Flanagan JU, Jowsey IR (2005) Glutathione transferases. Annu Rev Pharmacol Toxicol 45:51-88. https://doi.org/10.1146/annurev.pharmtox.45.120403.095857

39. Hermes-Lima M, Storey KB (1993) In vitro oxidative inactivation of glutathione-s-transferase from a freeze tolerant reptile. Molecular cellular biochemistry 124(2):149-158. https://doi.org/10.1007/BF00929207

40. Jaafar SNT, Coelho AV, Sheehan D (2015) Redox proteomic analysis of Mytilus edulis gills: effects of the pharmaceutical diclofenac on a non-target organism. Drug Test Anal 7(10):957-966. https://doi.org/10.1002/dta.1786

41. Kilty C, Doyle S, Hassett B, Manning F (1998) Glutathione-s-transferases as biomarkers of organ damage: applications of rodent and canine GST enzyme immunoassays. Chemico-Biol Interact 111:123-135

42. https://doi.org/10.1016/S0009-2797(97)00156-7

43. Le DQ, Tanaka K, Dung LV, Siau YF, Lachs L, Kadir STSA, Shirai K (2017) Biomagnification of total mercury in the mangrove lagoon food web in east coast of Peninsula, Malaysia. Regional Studies in Marine Science, 16, 49-55. https://doi.org/10.1016/j.rsma.2017.08.006

44. Lim PT, Gires U, Leaw CP (2012) Harmful algal blooms in Malaysian waters. Sains Malaysiana 41(12):1509-1515 
45. Lim PT, Leaw CP, Kobiyama A, Ogata T (2010) Growth and toxin production of tropical Alexandrium minutum Halim (Dinophyceae) under various nitrogen to phosphorus ratios. J Appl Phycol 22(2):203-210. https://doi.org/10.1007/s10811-009-9443-8

46. Loganathan B, Ramesh A, Venugopalan VK (1989) Pathogenic bacteria associated with Lates calcarifer and Ambassis commersoni. MIRCEN journal of applied microbiology biotechnology 5(4):463-467. https://doi.org/10.1007/BF01741822

47. Maulvault AL, Barbosa V, Alves R, Custodio A, Anacleto P, Repolho T, Diniz M (2017) Ecophysiological responses of juvenile seabass (Dicentrarchus labrax) exposed to increased temperature and dietary methylmercury. Science of The Total Environment 568:551-558.

https://doi.org/10.1016/j.scitotenv.2017.02.016

48. McCord JM, Fridovich I (1969) Superoxide dismutase an enzymic function for erythrocuprein (hemocuprein). Journal of Biological chemistry 244(22):6049-6055

49. Menezes C, Leitemperger J, Murussi C, de Souza Viera M, Adaime MB, Zanella R, Loro VL (2016) Effect of diphenyl diselenide diet supplementation on oxidative stress biomarkers in two species of freshwater fish exposed to the insecticide fipronil. Fish Physiol Biochem 42(5):1357-1368. https://doi.org/10.1007/s10695-016-0223-5

50. Monteiro DA, Rantin FT, Kalinin AL (2010) Inorganic mercury exposure: toxicological effects, oxidative stress biomarkers and bioaccumulation in the tropical freshwater fish matrinxã, Brycon amazonicus (Spix and Agassiz, 1829). Ecotoxicology 19(1):105. https://doi.org/10.1007/s10646009-0395-1

51. Nor NM, Yazid SHM, Daud HM, Azmai MA, Mohamad N (2019) Cost and management practices of Asian seabass (Lates calcarifer Bloch, 1970) cage culture in Malaysia using stochastic model that includes uncertainty in mortality. Aquaculture 510:347-352.

https://doi.org/10.1016/j.aquaculture.2019.04.042

52. Oliva M, Vicente JJ, Gravato C, Guilhermino L, Galindo-Riaño MD (2012) Oxidative stress biomarkers in Senegal sole, Solea senegalensis, to assess the impact of heavy metal pollution in a Huelva estuary (SW Spain): seasonal and spatial variation. Ecotoxicol Environ Saf 75:151-162. https://doi.org/10.1016/j.ecoenv.2011.08.017

53. Oliveira M, Pacheco M, Santos MA (2008) Organ specific antioxidant responses in golden grey mullet (Liza aurata) following a short-term exposure to phenanthrene. Sci Total Environ 396(1):70-78. https://doi.org/10.1016/j.scitotenv.2008.02.012

54. Othman MF, Hashim M, Yeo ME, Azmai MNA, Iksan N, Ho GC, Merican Z (2017) Transforming the Aquaculture Industry in Malaysia. World Aquaculture Society, 15-23

55. Parvez S, Raisuddin S (2006) Effects of paraquat on the freshwater fish Channa punctata (Bloch): non-enzymatic antioxidants as biomarkers of exposure. Arch Environ Contam Toxicol 50(3):392-397

56. https://doi.org/10.1007/s00244-005-5083-4

57. $10.1155 / 2014 / 671539$ 
Poljšak B, Fink R (2014) The protective role of antioxidants in the defence against ROS/RNSmediated environmental pollution. Oxidative medicine and cellular longevity, 2014.

https://doi.org/10.1155/2014/671539

58. Rainville LC (2015) Proteomic approach to oxidative stress in Daphnia magna. Dissertation. University College Cork

59. Rossi R, Dalle-Donne I, Milzani A, Giustarini D (2006) Oxidized forms of glutathione in peripheral blood as biomarkers of oxidative stress. Clinical chemistry 52(7):1406-1414. https://doi.org/10.1373/clinchem.2006.067793

60. Samanta P, Im H, Na J, Jung J (2018) Ecological risk assessment of a contaminated stream using multi-level integrated biomarker response in Carassius auratus. Environ Pollut 233:429-438. https://doi.org/10.1016/j.envpol.2017.10.061

61. Senapin S, Dong HT, Meemetta W, Gangnonngiw W, Sangsuriya P, Vanichviriyakit R, Nuangsaeng B (2019) Mortality from scale drop disease in farmed Lates calcarifer in Southeast Asia. J Fish Dis 42(1):119-127. https://doi.org/10.1111/jfd.12915

62. Shaari H, Mohd MS, Abdullah NA, Bidai J (2015) Heavy metals monitoring in Psammotaea elongata from Semerak Lagoon, Kelantan, Malaysia. Orient J Chem 31(2):993-999. https://doi.org/10.13005/ojc/310246

63. Shaari H, Raven B, Sultan K, Mohammad Y, Yunus K (2016) Status of heavy metals concentrations in oysters (Crassostrea sp.) from Setiu Wetlands. Terengganu Malaysia Sains Malaysiana 45(3):417424

64. Simonato JD, Mela M, Doria HB, Guiloski IC, Randi MA, Carvalho PS, Martinez CB (2016) Biomarkers of waterborne copper exposure in the Neotropical fish Prochilodus lineatus. Aquatic toxicology 170:31-41

65. https://doi.org/10.1016/j.aquatox.2015.11.012

66. Song Y, Salbu B, Heier LS, Teien HC, Lind OC, Oughton D, Tollefsen KE (2012) Early stress responses in Atlantic salmon (Salmo salar) exposed to environmentally relevant concentrations of uranium. Aquatic toxicology 112:62-71. https://doi.org/10.1016/j.aquatox.2012.01.019

67. Strange RC, Spiteri MA, Ramachandran S, Fryer AA (2001) Glutathione-s-transferase family of enzymes. Mutation Research/Fundamental Molecular Mechanisms of Mutagenesis 482(1-2):2126. https://doi.org/10.1016/S0027-5107(01)00206-8

68. Suratman S, Hussein ANAR, Latif MT, Weston K (2014) Reassessment of physico-chemical water quality in Setiu Wetland. Malaysia Sains Malaysiana 43(8):1127-1131

69. Tabassum H, Dawood AQ, Sharma P, Khan J, Raisuddin S, Parvez S (2016) Multi-organ toxicological impact of fungicide propiconazole on biochemical and histological profile of freshwater fish Channa punctata Bloch. Ecological indicators 63:359-365. https://doi.org/10.1016/j.ecolind.2015.11.052

70. Tedesco S, Sheehan D (2012) Protein thiols as novel biomarkers in ecotoxicology: a case study of oxidative stress in Mytilus edulis sampled near a former industrial site in Cork Harbour. Ireland Journal of Integrated OMICS 2(2):39-47. https://doi.org/10.5584/jiomics.v2i2.77 
71. Vallabh NA, Romano V, Willoughby CE (2017) Mitochondrial dysfunction and oxidative stress in corneal diseases. Mitochondrion 36:103-113

72. https://doi.org/10.1016/j.mito.2017.05.009

73. Yang HY, Lee TH (2015) Antioxidant enzymes as redox-based biomarkers: a brief review. BMB Rep 48(4):200. https://doi.org/10.5483/BMBRep.2015.48.4.274

74. Yap CK, Chew W (2011) A higher bioavailability and contamination of trace metals in Pantai Lido than Sungai Semerak: Evidence from trace metal concentrations in Polymesoda expansa and surface sediments. Malaysian Applied Biology Journal 40(1):55-59

75. Yusoff A (2015) Status of resource management and aquaculture in Malaysia. In Resource Enhancement and Sustainable Aquaculture Practices in Southeast Asia: Challenges in Responsible Production of Aquatic Species: Prodeedings of the International Workshop on Resource Enhancment and Sustainable Aquaculture Practices in Southeast Asia 2014 (RESA) (pp. 53-65). Aquaculture Department, Southeast Asian Fisheries Development Center

\section{Figures}




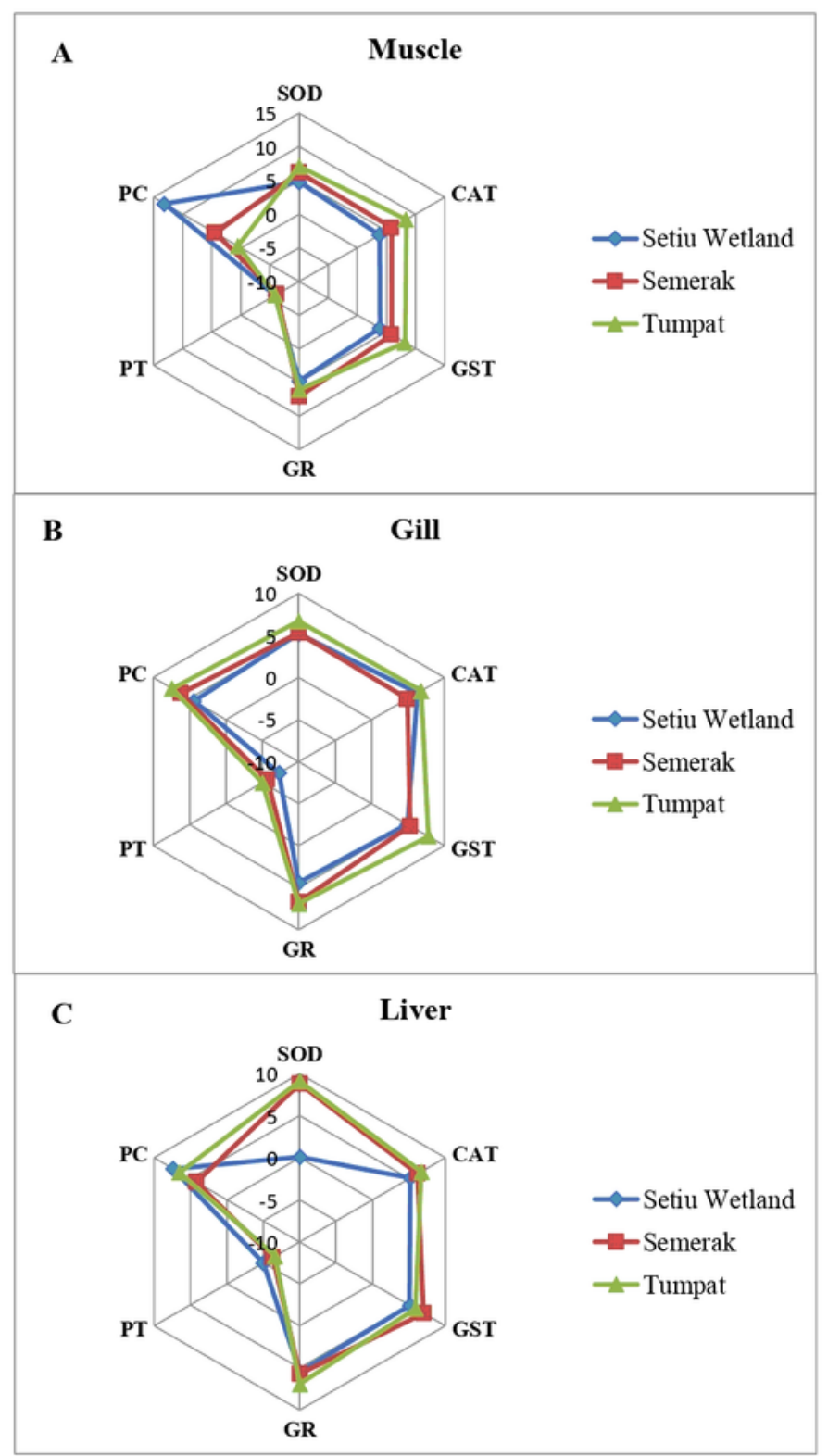

\section{Figure 1}

Sampling locations. A; (Tumpat, 540ه $47 \mathrm{~N}, 102^{\circ} 42 ه 51 \mathrm{E}$ ), B; (Semerak, $\left.5^{\circ} 5157 \mathrm{~N}, 102^{\circ} 2940 \mathrm{E}\right), \mathrm{C}$; (Setiu, $6^{\circ} 12 \searrow 50 \mathrm{~N}, 102^{\circ} 07 \rrbracket 49 \mathrm{E}$ ). 

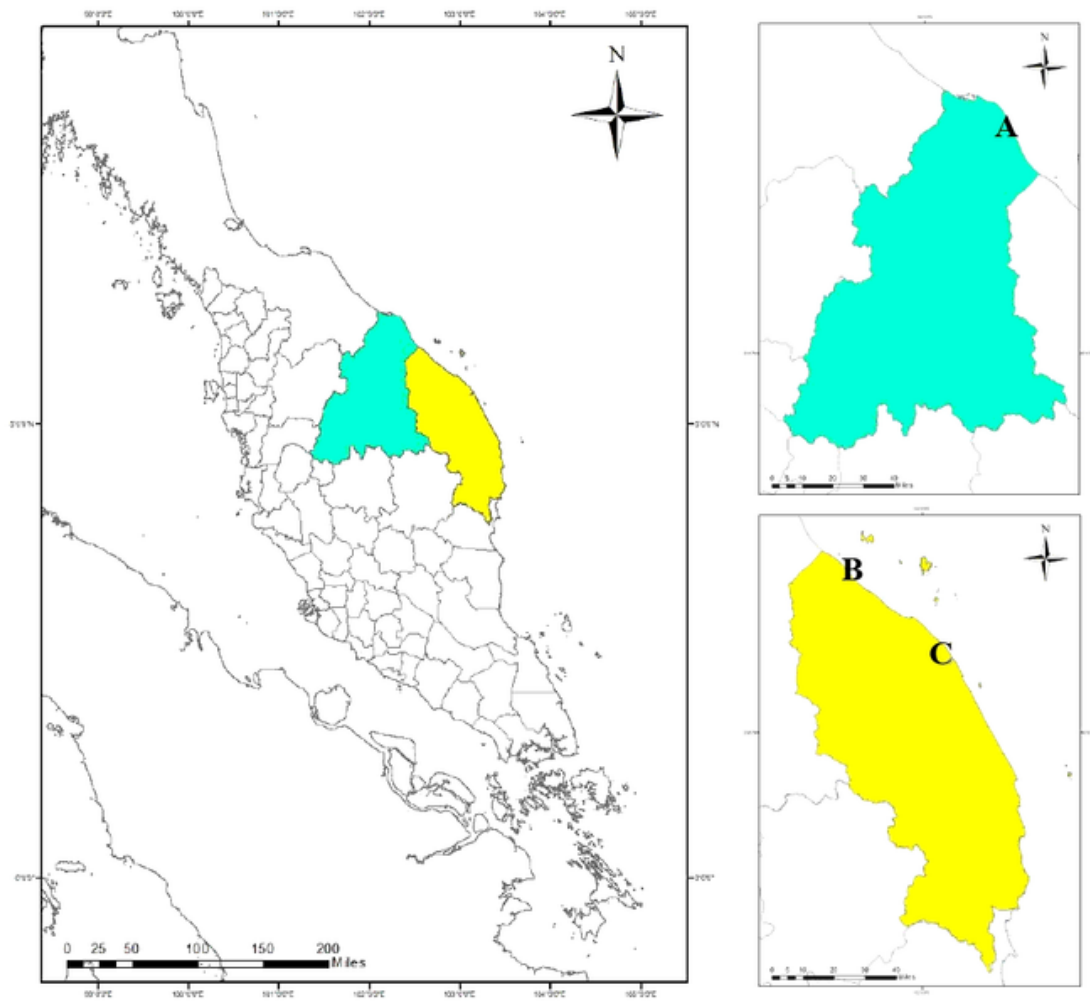

\section{Figure 2}

SOD and CAT activity in muscle, gills and liver tissue of L. calcarifer from Setiu Wetland, Semerak and Tumpat, Each value is mean \pm standard deviation, SD. $n=20 *$ Superscripts of different letters are significantly different from each other at (One way ANOVA, $p<0.05), n=20$ 

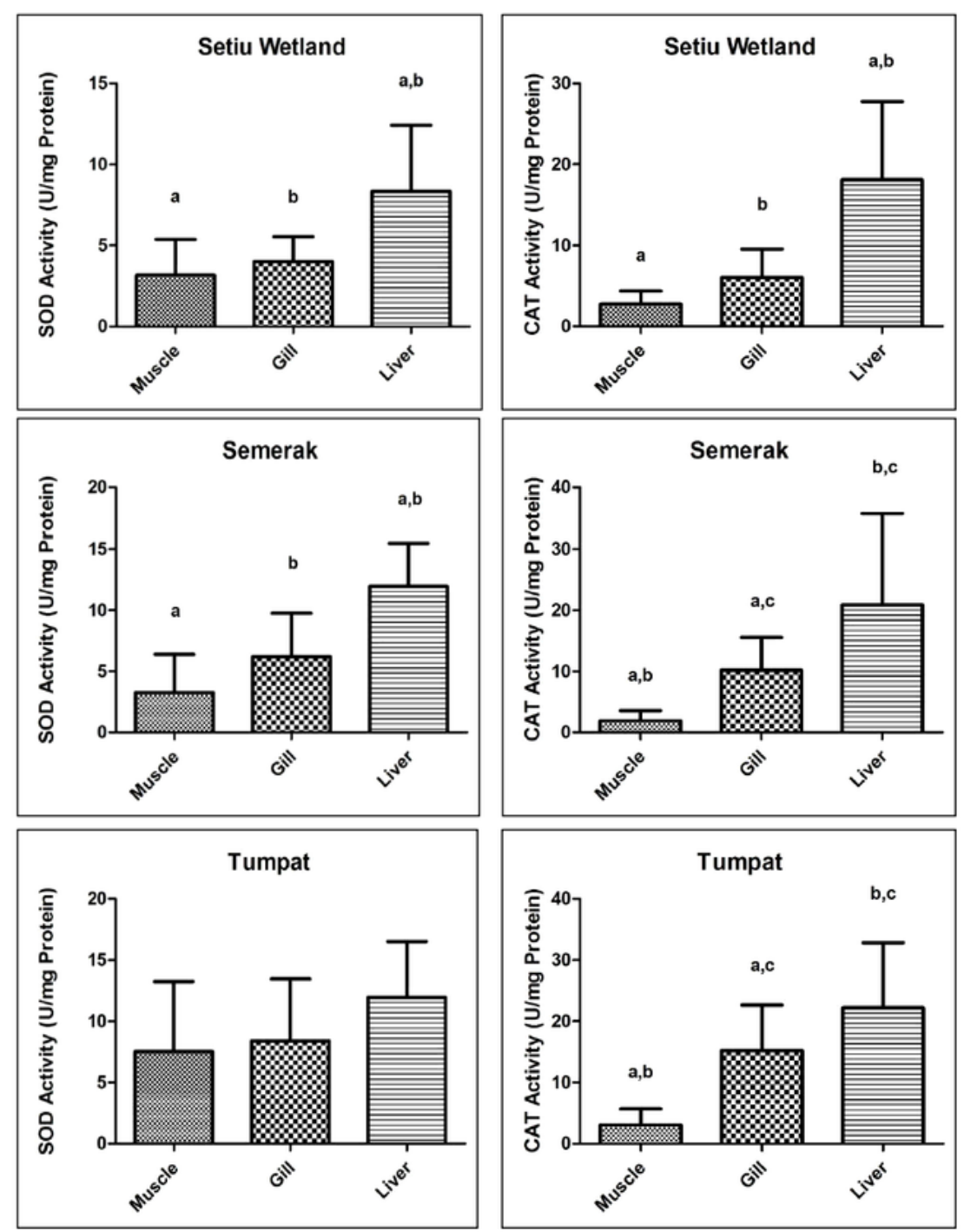

Figure 3

SOD and CAT response level in muscle, gills and liver tissue of L. calcarifer from Setiu Wetland, Semerak and Tumpat, Each value is mean \pm standard deviation, $S D, n=20$ * Indicates, (Paired t-test, $p<0.05$ ) 

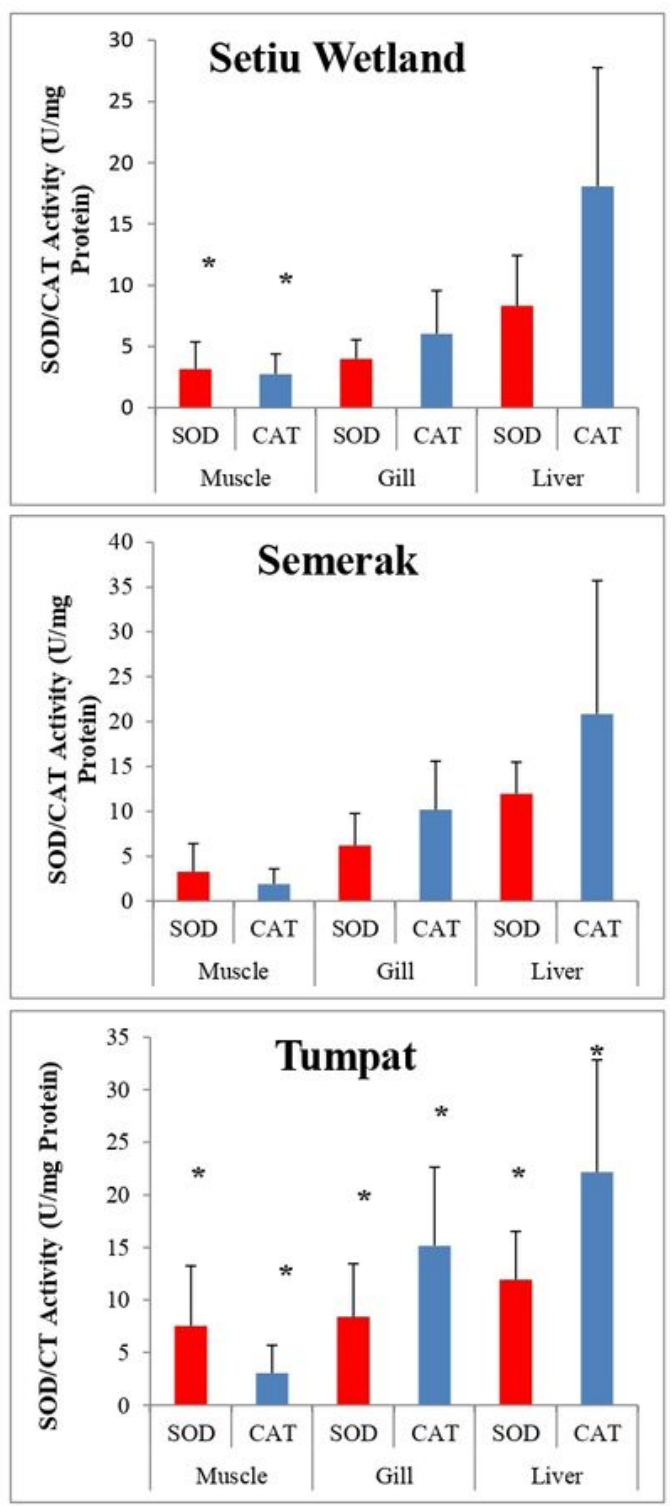

\section{Figure 4}

GST and GR activity in muscle, gills and liver tissue of L. calcarifer from Setiu Wetland, Semerak and Tumpat, Each value is mean \pm standard deviation, SD. $n=20 *$ Superscripts of different letters are significantly different from each other at (One way ANOVA, $p<0.05), n=20$ 

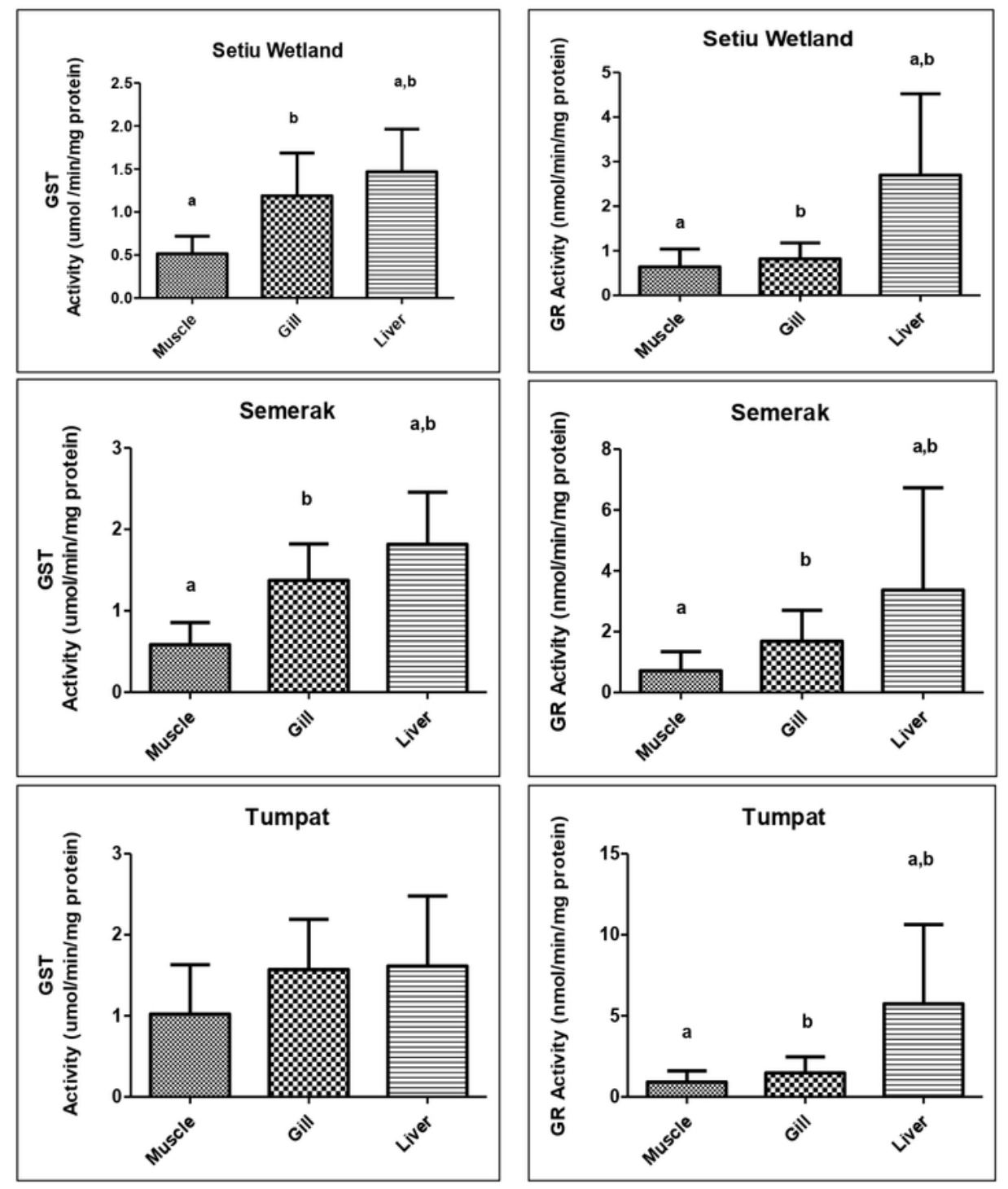

\section{Figure 5}

1DE of thiol-containing proteins and carboyl-containing protein in muscle, gills and liver of L.calcarifer collected in Setiu Wetland, Semerak and Tumpat. Data are expressed in A.U. as mean \pm Standard deviation. *Superscripts of different letters are significantly different from each other at (One way ANOVA, $p<0.05), n=20$ 

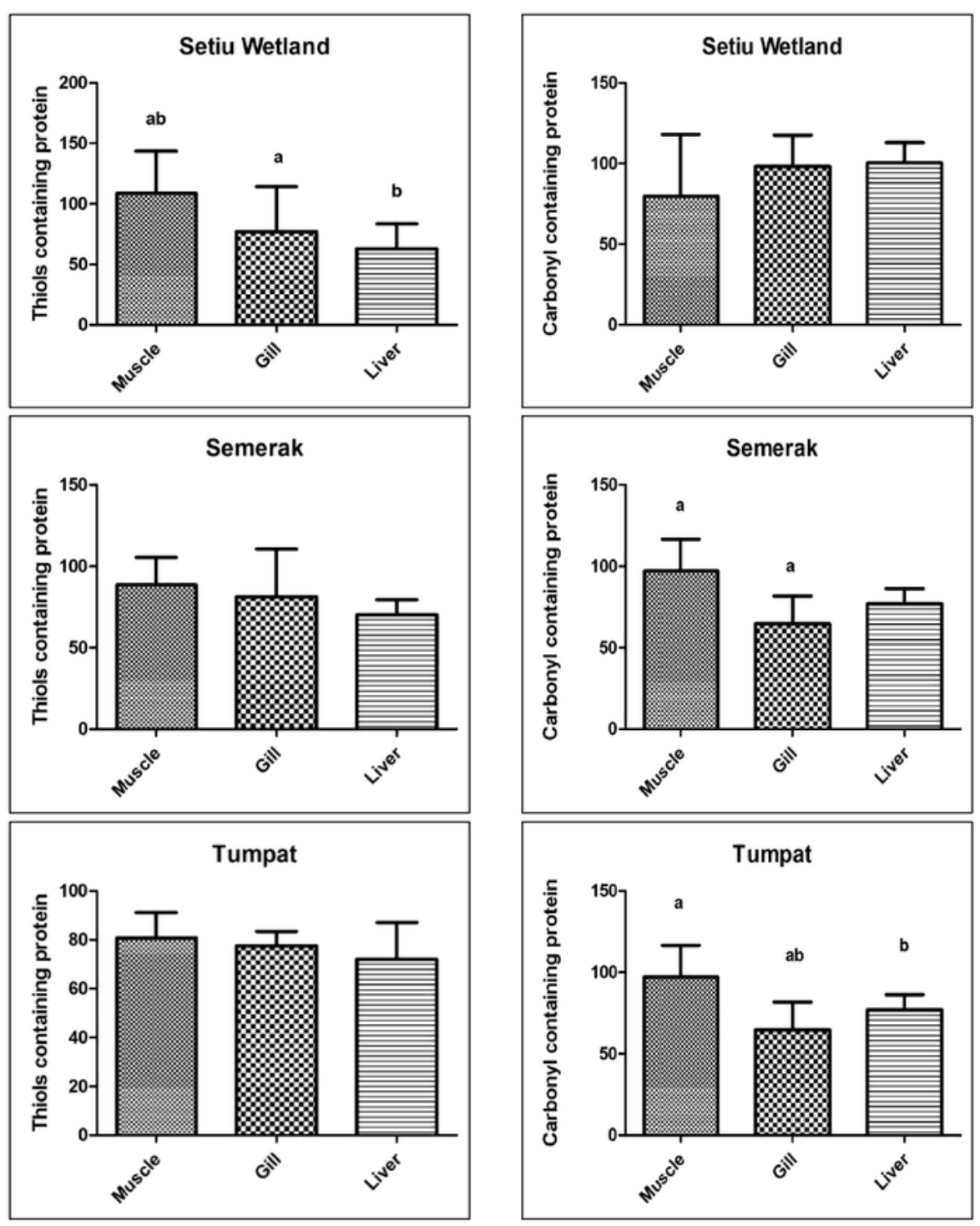

\section{Figure 6}

The Integrated Biomarker Responses (IBR) following the response of Superoxidase dismutase (SOD), Catalase (CAT), Glutathione-s-transferase (GST), Glutathione reductase (GR), Protein thiols (PT) and Protein carbonyls (PC) in muscle (6A), gill (6B) and liver (6C). The plots above 0 reflect the induction of the biomarker and the plots below 0 reflects inhibition of the biomarker. 


\section{Supplementary Files}

This is a list of supplementary files associated with this preprint. Click to download.

- GraphicalAbstractimages.pdf 